\title{
Dietary macronutrient recommendations for optimal recovery post-exercise: Part II
}

\author{
H H Wright (MSc Dietetics, PhD Nutrition) ${ }^{1}$ \\ A Claassen (BSc (Hons) Dietetics, BSc (Med) (Hons) Exercise Science) ${ }^{2}$ \\ J Davidson (DSc) ${ }^{3}$ \\ ${ }^{1}$ Potchefstroom Institute of Nutrition, Faculty of Health Sciences, Northwest University, South Africa \\ ${ }^{2}$ UCT/MRC Research Unit for Exercise Science and Sports Medicine, Faculty of Health Sciences, University of Cape Town, South Africa \\ ${ }^{3}$ College of Education and Health Sciences, Bradley University, Peoria, Illinois, USA
}

\begin{abstract}
A net positive nitrogen balance is needed for exerciseinduced muscle damage to be repaired during the recovery period. Apart from hormones and growth factors, adequate energy and amino acid availability contribute to this balance and influence the rate at which protein synthesis and muscle repair occur post-exercise. This paper reviews the dietary factors involved in muscle repair during the post-exercise recovery period. Both resistance and endurance-trained athletes have a higher dietary protein requirement of between 1.2 and $1.8 \mathrm{~g}$ protein $/ \mathrm{kg}$ body weight $(\mathrm{BW}) /$ day, with an upper limit of $2 \mathrm{~g}$ protein $/ \mathrm{kg}$ $\mathrm{BW} /$ day. To increase the rate of protein synthesis during the recovery period, immediate ingestion of protein postexercise is recommended. Additionally, ingesting $1.2 \mathrm{~g}$ carbohydrate $(\mathrm{CHO}) / \mathrm{kg} \mathrm{BW/hour} \mathrm{with} 0.4 \mathrm{~g} / \mathrm{kg} \mathrm{BW} / \mathrm{hour}$ of a wheat amino acid mixture (wheat protein hydrolysate combined with free leucine and phenylalanine) enhances the insulin response compared with ingesting $\mathrm{CHO}$ only or combined with other protein hydrolysates, peptides, or intact protein. This increased insulin response could increase muscle protein synthesis indirectly by altering the hormonal milieu. Results on the anabolic effect of single or mixtures of amino acids remains to be further elucidated. The possible antioxidant benefits of whey protein supplementation in athletes remains to be proven, while the antioxidant potential of soy protein holds promise. The effect of glutamine supplementation on protein synthesis in athletes is limited and its clinical relevance for
\end{abstract}

\section{CORRESPONDENCE:}

H Wright

School of Physiology, Nutrition and Consumer Science

North-West University

Private Bag X6001

Potchefstroom, 2531

Tel: 018-299 2482

Fax: 018-299 2464

E-mail: vgehhw@puk.ac.za enhanced immune function in endurance athletes remains to be established. Creatine supplementation seems to be beneficial in terms of protein synthesis and gains in fat free mass during the recovery period, while the use $\beta$-hydroxy $\beta$-methylbutyrate (HMB) supplementation by trained athletes seems to have limited benefits. It is important to keep dietary advice individualised considering the complexity in which the endocrine system regulates cell function, the diverse mechanisms that control homeostasis, as well as genetic variability.

\section{Introduction}

Protein turnover (protein synthesis and breakdown) is typically increased during and post-exercise. With heavy resistance exercise certain muscle fibres are disrupted or damaged and need to undergo a remodelling and repair process during the recovery period. ${ }^{16}$ For a detailed review of exercise-induced muscle damage and inflammation see Pyne. ${ }^{56}$ Muscle damage or disruption (protein breakdown) is influenced by the duration, intensity and type of exercise (eccentric vs. concentric), as well as training status. ${ }^{16}$ It has been shown that with regular exercise training, the rise in protein breakdown is attenuated. ${ }^{54}$ During endurance-type training there is also an increase in protein breakdown in order to sustain exercise metabolism, which increases when muscle glycogen stores are depleted.

In order for muscle repair, recovery and adaptation to take place post-exercise, a positive nitrogen balance is needed in order to allow for a state of net protein synthesis. ${ }^{71}$ This shift from a catabolic to anabolic state is mediated by the presence of certain dietary nutrients, hormones and growth factors. ${ }^{71}$ Protein synthesis and skeletal muscle repair post-exercise have been shown to increase in response to adequate energy and amino acid availability, while protein breakdown is decreased by insulin. ${ }^{68}$ Furthermore, resistance exercise and amino acid availability have additive effects in terms of protein synthesis. ${ }^{6}$ This article (Part II) will focus on dietary factors that contribute to protein synthesis and skeletal muscle repair during the recovery period. 


\section{Dietary factors involved in muscle repair}

\section{Overall dietary protein requirements with regular exercise training}

Intensive and/or high-volume aerobic and weight-training exercise increase the protein requirement for muscle repair, adaptation, and to remain in positive nitrogen balance. ${ }^{1}$ During prolonged endurance exercise, protein may also contribute as fuel to the overall energy demand, however, this contribution remains small $(<5-10 \%)$, with carbohydrate $(\mathrm{CHO})$ and fat contributing to most of the energy demand. ${ }^{60}$ At the onset of a training programme, protein requirements may be slightly higher compared with the latter part of a training cycle where adaptation has already taken place. ${ }^{40} \mathrm{~A}$ range of $1.2-1.8 \mathrm{~g}$ protein $/ \mathrm{kg}$ body weight $(\mathrm{BW}) /$ day is recommended for resistance and/or endurance-trained athletes, however, an upper limit for protein ingestion has been set at $2 \mathrm{~g} / \mathrm{kg} \mathrm{BW} /$ day beyond which there is no added benefit of ingesting more protein. Ingesting $>2 \mathrm{~g}$ protein $/ \mathrm{kg} \mathrm{BW} /$ day will not enhance muscle repair and adaptation any further, ${ }^{1}$ and may be detrimental to health. ${ }^{23}$ One exception would be athletes training at high altitude, which elicits a greater catabolic response and increases protein requirements to $\sim 2.2$ $\mathrm{g}$ protein $/ \mathrm{kg} \mathrm{BW} / \mathrm{day}$ in order to remain in positive nitrogen balance. ${ }^{66}$

\section{Timing of protein intake}

An amino acid tracer infusion study $(\sim 0.15 \mathrm{~g}$ amino acid mixture/kg BW/hour for 3 hours) by Biolo and co-workers ${ }^{6}$ indicated an increased rate of muscle protein synthesis with hyperaminoacidaemia post-exercise compared with rest. This was supported by Rasmussen and co-workers ${ }^{58}$ who found that ingesting an essential amino acid-CHO supplement ( $6 \mathrm{~g}$ amino acids $+35 \mathrm{~g}$ sucrose/serving) at 1 or 3 hours after resistance exercise resulted in similar rates of muscle protein synthesis, which was $\sim 400 \%$ above pre-drink values. Levenhagen and co-workers ${ }^{42}$ then showed that ingesting a high-protein supplement $(10 \mathrm{~g}$ protein $+8 \mathrm{~g} \mathrm{CHO}$ $+3 \mathrm{~g}$ fat/serving) immediately after an exercise bout (cycling for 60 minutes at $60 \%$ maximal oxygen uptake $\left(\mathrm{VO}_{2 \max }\right)$ ) enhanced whole-body protein synthesis three-fold compared with delayed ingestion ( 3 hours post-exercise), and significantly increased dynamic and isokinetic strength. ${ }^{19}$

Levenhagen and co-workers ${ }^{41}$ also investigated the potential of nutrient intake post-exercise in terms of enhanced recovery of whole-body and skeletal muscle protein homeostasis. Subjects were given either a placebo, a $\mathrm{CHO}$-fat supplement ( $8 \mathrm{~g} \mathrm{CHO}+3 \mathrm{~g}$ fat/serving), or a $\mathrm{CHO}$-proteinfat supplement $(8 \mathrm{~g} \mathrm{CHO}+10 \mathrm{~g}$ protein $+3 \mathrm{~g}$ fat/serving $)$ immediately after a 60-minute exercise period (cycling at $60 \% \mathrm{VO}_{2 \max }$ ). After a 2-hour recovery period there was a net gain in whole-body protein and leg protein in the $\mathrm{CHO}$-protein-fat supplement group, while the placebo and $\mathrm{CHO}$-fat supplement group resulted in a net loss in the same measurements. From these results it can be concluded that amino acid availability post-exercise is more important than energy for muscle repair and synthesis during recovery. A study by Tipton and co-workers ${ }^{70}$ found an increased rate of muscle protein synthesis 1 hour after resistance exercise when an oral essential amino acid-CHO supplement (35 g sucrose $+6 \mathrm{~g}$ essential amino acids) were given prior to the exercise bout compared with immediately afterwards. The main contributor to this increase was an increased delivery of amino acids to the muscle when ingested prior to exercise.

In summary, it seems that the earlier amino acids are available post-exercise, the quicker a positive nitrogen balance can be achieved which could contribute to increased muscle protein synthesis, hypertrophy and strength. Ingestion of protein or amino acids prior to exercise might have beneficial effects on enhancing post-exercise recovery, however, further research is needed to confirm this effect. Furthemore, pre-exercise protein ingestion may have ergolytic effects due to increased ammonia production (explained in more detail later). ${ }^{13,43}$

\section{Type of protein and amino acids}

Since amino acids and their metabolites are involved in muscle repair, ${ }^{6}$ post-exercise ingestion of intact protein, or supplementation with specific amino acids and their metabolites has been suggested to optimise muscle repair and adaptation.

Adequate essential amino acids may be derived from the ingestion of intact protein, either in animal or soy-based foods. ${ }^{78}$ Available protein products include whey protein, milk isolates, caseinates, soy isolates, and other vegetable proteins. There is no consensus regarding which protein type is the best. It is important to note that ingestion of amino acids, when dietary protein intake is sufficient, does not further increase the rate of muscle repair. ${ }^{66}$ Furthermore, unrestricted supplementation with single amino acids or amino acid mixtures is associated with metabolic imbalances, toxicity, as well as degeneration of myofibrils and disrupted mitochondrial membranes. . $3: 37^{3}$

\section{Protein peptides/hydrolysates}

Van Loon and co-workers ${ }^{73}$ investigated the insulinotrophic effect of various drinks containing $0.8 \mathrm{~g} \mathrm{CHO} / \mathrm{kg} \mathrm{BW} /$ hour combined with $0.4 \mathrm{~g} / \mathrm{kg} \mathrm{BW} /$ hour of different combinations of amino acids and/or protein sources ingested under resting conditions. The drinks were given at 30 -minute intervals over a 2-hour period. Their main finding was that the oral intake of $0.4 \mathrm{~g} / \mathrm{kg} \mathrm{BW} /$ hour of wheat protein hydrolysate combined with free leucine and free phenylalanine in the postabsorptive, resting state can produce a larger ( 100\%) insulin response when compared with the ingestion of $\mathrm{CHO}$ only, and comparable with the ingestion of a drink containing $0.4 \mathrm{~g} / \mathrm{kg} \mathrm{BW} / \mathrm{hour}$ of free leucine, free phelylalanine and arginine. This drink, however, did not produce the severe symptoms of gastro-intestinal upset and diarrhoea that was observed with the ingestion of drinks containing large doses of free amino acids, particularly free leucine, arginine, phenylalanine and glutamine. ${ }^{73}$

When comparing the ingestion of protein hydrolysates with intact protein, it was concluded that the use of protein hydrolysates is more preferable seeing that it results in a faster increase in plasma amino acid concentrations and stimulation of insulin secretion during a 2-hour period compared with intact protein. ${ }^{73}$ 
Subsequently, Van Loon et al..$^{72}$ investigated the insulinotrophic effects of post-exercise ingestion of $1.2 \mathrm{~g}$ $\mathrm{CHO} / \mathrm{kg} \mathrm{BW} /$ hour combined with differing amounts of wheat protein hydrolysate $(0.2$ or $0.4 \mathrm{~g} / \mathrm{kg} \mathrm{BW} /$ hour), with or without free leucine and phenylalanie at 30-minute intervals up to 3 hours post-exercise in trained men. Ingestion of wheat hydrolysate only (either 0.2 or $0.4 \mathrm{~g} / \mathrm{kg} \mathrm{BW} /$ hour) combined with $1.2 \mathrm{~g} \mathrm{CHO} / \mathrm{kg} \mathrm{BW} /$ hour did not increase post-exercise insulin response compared with the ingestion of $1.2 \mathrm{~g} / \mathrm{kg}$ $\mathrm{BW} /$ hour of $\mathrm{CHO}$ only. However, addition of free leucine and phenylalanine resulted in a substantial increase in insulin response. Additionally, a dose-related effect existed seeing that increasing the amount of wheat-amino acid mixture from 0.2 to $0.4 \mathrm{~g} / \mathrm{kg} \mathrm{BW} /$ hour resulted in a significant increase in the insulin response. Furthermore, a strong positive correlation between insulin response and plasma leucine, pheylanaline and tyrosine concentrations existed. ${ }^{73}$ Increased plasma amino acid concentrations may directly (by providing substrate) and indirectly (by altering the anabolic hormonal milieu) increase muscle protein synthesis (for review see Tessari and co-workers ${ }^{68}$ ).

Commercially, whey protein is marketed as a superior protein by manufacturers not only due to its high-quality protein, but also due to its bio-availability and ease of dispersion in supplements and bars. Compared with other protein sources, whey has been found to contain a higher complement of essential amino acids (EAAs) and branched-chain amino acids (BCAAs), and to result in greater biological value in humans. ${ }^{38}$ Additionally, whey protein contains more cysteine than casein. Cysteine is considered important for glutathione (potent antioxidant) production. ${ }^{12}$ It is due to this characteristic that it is hypothesised that the ingestion of whey protein post-exercise may protect against exerciseinduced free radical damage. Though a number of studies (mostly done on animals) have demonstrated positive immune system benefits and antioxidant action with whey protein supplementation, these effects remain to be proven in physically active human populations.

Soy protein also offers a high-quality protein, which is equivalent to casein and egg protein ${ }^{78}$ and may therefore also contribute to protein synthesis if ingested post-exercise. Additionally because of its high content of genistein and other phytochemicals, soy may have advantages in improving post-exercise recovery by increasing its antioxidant potential which could attenuate muscle breakdown. ${ }^{3}$ Research investigating these possible effects during and post-exercise by evaluating skeletal muscle repair, oxidative function, antioxidant mechanisms, and immune function are, however, limited. Two studies in athletes demonstrated reduced exercise-induced antioxidant stress and muscle damage after consumption of a soy beverage post-exercise. ${ }^{3,62}$

\section{Single amino acids and amino acid mixtures}

It has been suggested that supplementation of single amino acids or amino acid mixtures may attenuate the hormonal milieu (e.g. stimulate insulin and growth hormone release) with subsequent anabolic effects on protein metabolism, ${ }^{68}$ and/or directly stimulate the rate of muscle repair compared with the ingestion of intact protein. ${ }^{35}$
In vitro studies have shown that particularly leucine phenylalanine, arginine and glutamine have powerful stimulating effects on insulin release by pancreatic $\beta$-cells. ${ }^{7}$ Floyd and co-workers ${ }^{20}$ reported that intravenous injection of $30 \mathrm{~g}$ of arginine in humans resulted in a similar insulin response as found with the injection of a $30 \mathrm{~g}$ amino acids mixture (arginine, lysine, phehylalanine, leucine, valine, methionine, histidine, isoleucine, threonine, and tryptophane). In contrast, Van Loon and co-workers ${ }^{73}$ demonstrated that oral ingestion of a large dose of arginine $(0.4 \mathrm{~g} / \mathrm{kg} \mathrm{BW} / \mathrm{hour})$ was not effective in increasing plasma arginine or insulin concentrations. This was probably due to poor intestinal absorption of arginine due to severe diarrhoea that was elicited after ingestion. ${ }^{73}$ These results indicate that oral administration of large doses of arginine (and perhaps also other single amino acids) to stimulate growth hormone release and muscle anabolism should be practised with caution and is best avoided.

Blomstrand and Saltin ${ }^{10}$ investigated the influence of a BCAA supplement $(150 \mathrm{ml}$ containing $45 \%$ leucine, $30 \%$ valine, $25 \%$ isoleucine) given 15 minutes before exercise, at 15 -minute intervals during 1 hour of 1 -legged exercise and at $15,30,60$ and 90 minutes of recovery on muscle protein metabolism. They found that the supplement had a proteinsparing effect during recovery, which seemed to be insulindependent. Results from other studies suggest that the protein-sparing effect could have been attributed to a decrease in the rate of protein degradation. ${ }^{17,47}$ In an earlier study, Blomstrand and Newsholme ${ }^{9}$ showed that the ingestion of $7.5 \mathrm{~g}$ BCAA during a $30 \mathrm{~km}$ cross-country race or full marathon decreased the net rate of exercise-induced protein degradation. Possible mechanisms proposed by Coombes and McNaughton ${ }^{17}$ include: (i) BCAAs increase anabolism and decrease catabolism, thus there is less damage to proteins associated with cell membranes; (ii) BCAAs increase sensitivity of muscle to anabolic actions of insulin, thereby increasing protein synthesis; (iii) BCAAs increase their own oxidation, thus limiting muscle damage; and (iv) BCAAs suppress degradation during and after sustained exercise via alpha-ketoisocaproate (KIC). BCAAs can increase KIC concentration which inhibits muscle proteolysis in vitro, thereby contributing to a decrease in degradation. ${ }^{17}$ No influence on exercise-induced hormonal response has, however, been found after 1 week of high-volume weight training and ingestion of $2.4 \mathrm{~g}$ amino acid supplement prior to each meal, as well as $2.1 \mathrm{~g}$ BCAA supplement prior to each workout session for 1 week. ${ }^{21}$

The ingestion of a large single dose $(\sim 300 \mathrm{mg} / \mathrm{kg} \mathrm{BW})$ of BCAA ingested 15 - 30 minutes before and/or during exercise has been shown to increase ammonia production during exercise. $^{43}$ After a series of observations Brouns and coworkers $^{13}$ hypothesised that high intramuscular ammonia concentration may be related to the aetiology of muscle exhaustion during prolonged, strenuous endurance exercise. Other studies found no effect of BCAA ingestion on ammonia production, especially with low amounts $(<100 \mathrm{mg} / \mathrm{kg}$ BW) ingested as multiple smaller doses before or during exercise. ${ }^{8,46}$

Enhanced responsiveness of the pituitary corticotrophin and gonadotropin secretory cells to their releasing hormones (e.g. growth hormone) has been shown 60 minutes after the 
ingestion of an amino acid mixture $(100 \mathrm{mg}$ arginine/kg BW $+80 \mathrm{mg}$ ornithine/kg BW + $140 \mathrm{mg} \mathrm{BCAA}+10 \mathrm{~g}$ glucose/serving).$^{18}$ An earlier study ${ }^{36}$ showed no influence on growth hormone concentration after the ingestion of three different amino acid drinks according to manufacturer's instructions (drink $A=2.4 \mathrm{~g} \mathrm{~L}$-arginine/L-lysine/serving; drink $\mathrm{B}=1.1 \mathrm{~g}$ L-ornithine, $750 \mathrm{mg}$ pyridoxine $\mathrm{HCL}, 125 \mathrm{mg}$ ascorbic acid; drink $\mathrm{C}=20 \mathrm{~g}$ Bovril: $7.8 \mathrm{~g}$ protein, $580 \mathrm{mg} \mathrm{CHO}$, $146 \mathrm{~kJ}$ ) after an 8-hour fast. It can be concluded that growth hormone secretion may be affected by the type of amino acid, its dosage and the specific combination of amino acids ingested, but more research is needed to confirm these findings.

The question of EAA compared with mixed amino acid (MAA) supplements on protein synthesis has also sparked some interest. Tipton and co-workers ${ }^{69}$ found that the ingestion of either a MAA (40 g/serving) or EAA (40 g/serving) supplement after a resistance exercise protocol led to similar net positive protein balance compared with a negative protein balance with placebo ingestion. They therefore showed an anabolic response post-exercise, with or without EAA, which was also comparable to intravenous amino acid infusions. A more recent study ${ }^{11}$ found a significantly higher net muscle protein balance response after a resistance exercise protocol when an EAA (6 g/serving) supplement was ingested post-exercise compared with a non-EAA ( $3 \mathrm{~g}$ EAA $+3 \mathrm{~g}$ non-EAA/serving) supplement. It can be concluded from these studies that there might be a threshold for the amount of EAA needed to stimulate protein synthesis and that nonEAA is not necessary to achieve protein balance.

\section{Glutamine}

Glutamine is a major fuel source to the intestinal wall (brush border) and due to the high turnover of these cells they need a continual supply of amino acids for protein synthesis. ${ }^{77}$ Thus, cells of the intestine may be preferentially supplied with amino acids for oxidation and protein synthesis at the expense of skeletal muscle protein. ${ }^{28}$ It is therefore hypothesised that providing dietary glutamine can 'spare' intramuscular glutamine, while supplying the intestine with needed glutamine. This would contribute to a decrease in proteolysis secondary to lowered blood glutamine concentrations. Hankard and co-workers, ${ }^{25}$ however, found no change in glutamine release from proteolysis after a glutamine infusion study done at rest, whilst demonstrating an increase in protein synthesis during glutamine infusion at rest. ${ }^{26}$ It therefore seems that glutamine supplementation may have an anabolic effect based on its influence on protein synthesis. Additionally, glutamine has been reclassified as a conditionally essential amino acid during certain stressful conditions (including strenuous exercise). ${ }^{24}$ Most studies investigating the effect of glutamine on muscle protein metabolism have, however, been done in the clinical setting. Thus, studies investigating the direct influence of glutamine supplementation on muscle protein synthesis in athletes are limited.

Welbourne $^{75}$ showed an increased plasma growth hormone concentration 90 minutes after ingestion of $2 \mathrm{~g}$ glutamine over a 20-minute period. Whether chronic ingestion of glutamine will result in a continued increase is, however, not known. Glutamine supplementation $(0.35 \mathrm{~g} / \mathrm{kg} \mathrm{BW} /$ day for 14 days) in wrestlers consuming a hypocaloric diet resulted in the maintenance of a positive nitrogen balance, while the placebo group was in a negative nitrogen balance at the end of the supplementation period. ${ }^{61}$

Decreases in plasma glutamine concentrations has been shown after strenuous prolonged exercise, which could influence immune system regulation ${ }^{59}$ since glutamine is an important fuel source for lymphocytes and macrophages. ${ }^{2}$ Decreased glutamine concentrations have also been found in athletes suffering from 'over-trained syndrome'. ${ }^{48}$ The reduced glutamine concentrations seen after prolonged endurance-type exercise have been proposed to be a result of increased glutamine use by cells of the immune system. ${ }^{48}$ The effects of glutamine supplementation in endurance athletes on the immune system function are, however, contradicting (for review see Rohde and co-workers ${ }^{59}$ ). Thus, although glutamine supplementation to enhance immune system function is currently a popular practice amongst athletes, further scientific research is needed to establish the clinical relevance of glutamine supplementation in athletes in order to enhance immune system function.

\section{$\beta$-Hydroxy $\beta$-Methylbutyrate (HMB)}

$\mathrm{HMB}$ is a metabolite of leucine and has been suggested to increase strength and fat free mass (FFM). ${ }^{49}$ The metabolic function and fate of HMB are not fully understood (for a detailed review see Nissen and Abumrad ${ }^{49}$ ). Preliminary data suggests that HMB may be part of some structural component within tissues or membranes. ${ }^{49}$ The proposed mechanism of increased strength and FFM is thought to be linked to HMB's anti-catabolic effects and inhibition of proteolysis..$^{55}$ Leucine and KIC (an intermediate in leucine breakdown to $\mathrm{HMB}$ ) have both been shown to inhibit proteolysis. ${ }^{49}$

Most studies on HMB focus on its effect on FFM accretion and strength gains. The preponderance of data suggest an increase in FFM and strength with the supplementation of 1.5 - $3 \mathrm{~g} \mathrm{HMB} /$ day for at least 3 weeks combined with $\geq 2$ times/week resistance training..$^{22,30,50,52}$

Two clinical studies ${ }^{15,44}$ also found a decrease in protein degradation and increases in FFM when cachectic patients were supplemented with a HMB-mixture $(3 \mathrm{~g} \mathrm{HMB}+14 \mathrm{~g} \mathrm{~L}-$ glutamine $+14 \mathrm{~g} \mathrm{~L}$-arginine/day) for 8 weeks without physical activity compared with a placebo group.

Knitter and co-workers ${ }^{32}$ investigated the effect of HMB supplementation ( $3 \mathrm{~g} \mathrm{HMB} /$ day 6 weeks prior to and 4 days after a prolonged run) in endurance-trained males and females. The placebo group exhibited a significantly greater increase in creatine phosphokinase and lactate dehydrogenase activity compared with the HMB-supplemented group. These results suggest that HMB prevents exercise-induced muscle damage, which results have been supported by others. ${ }^{52}$

Kreider and co-workers, ${ }^{33}$ however, found no difference in whole body anabolic/catabolic markers, body composition, muscle enzyme efflux or one repetition maximum (1-RM) in resistance-trained men after 28 days of HMB supplementation (3 or $6 \mathrm{~g} \mathrm{HMB/day)} \mathrm{combined} \mathrm{with} 7$ hours/week resistance training. On the other hand, Panton and co-workers ${ }^{52}$ found that HMB supplementation ( $3 \mathrm{~g} \mathrm{HMB} /$ day for 4 weeks) combined with a resistance training programme increased body strength and minimised muscle damage regardless of 
gender or training status. A possible reason for discrepancy in results could be that training loads were inadequate in the study by Kreider and co-workers, ${ }^{33}$ since subjects' resistance training was not monitored on a day-by-day training basis. Additionally, lack of significance might have been due to small statistical power since there were small numbers of subjects per treatment group.

Lastly, the combination of HMB and creatine $(20 \mathrm{~g}$ creatine $+3 \mathrm{~g} \mathrm{HMB} /$ day for 7 days followed by $10 \mathrm{~g}$ creatine + $3 \mathrm{~g} \mathrm{HMB} /$ day for 14 days) during a weight-training programme has also been shown to increase body strength and FFM and their effects seem to be additive. ${ }^{30}$

It is, however, important to note that most studies that found a positive relationship between HMB and FFM or strength were done by the same research group. Furthermore, it is important to note that the majority of studies that showed an increase in $\mathrm{FFM}^{22,30}$ and/or strength ${ }^{22,30,52}$ were done on untrained subjects embarking on a training programme. Those studies done on trained individuals ${ }^{33,51,57,65}$ found no effect of HMB supplementation on measures of FFM and strength.

\section{Creatine}

Creatine is a naturally occurring compound derived from the amino acids glycine, arginine, and methionine. ${ }^{4}$ The daily requirement of creatine is approximately $2-3 \mathrm{~g}$ and can be obtained exogenously from the diet, primarily meat and fish, while the remainder is synthesised endogenously. ${ }^{4}$

Numerous studies have demonstrated that creatine supplementation is associated with an enhanced ability to perform repeated bouts of high-intensity exercise interspersed by short recovery periods mainly attributed to increased adenosine triphosphate (ATP) re-phosphorylation (for review see Beduschi ${ }^{4}$ ). Creatine supplementation typically consists of a loading phase ( 2 - 5 days) in which $20 \mathrm{~g}$ creatine/day (4 $x 5 \mathrm{~g}$ doses spread over the course of a day) is ingested, followed by a maintenance phase ( $\geq 3$ days) in which $2-5 \mathrm{~g}$ creatine/day is ingested. ${ }^{67}$

It is hypothesised that creatine supplementation can be beneficial during the recovery phase in terms of protein synthesis and gains in FFM. Many studies have reported a significant increase in FFM, ranging from 1 to $2.2 \mathrm{~kg}$ with creatine supplementation. ${ }^{5,34,67}$ The gain in body mass has traditionally mainly been attributed to water retention within the muscle due to increased cellular osmolarity. ${ }^{31,34}$ However, it has been suggested that creatine ingestion may also stimulate myofibrillar protein synthesis $\mathrm{s}^{27,67,76}$ and/or inhibit protein breakdown ${ }^{53}$ and thereby increase FFM. Another proposed mechanism includes an increased resynthesis of ATP which could allow for an increased training capacity and higher quality exercise bouts, thereby increasing exercise-induced stimulation of muscle protein synthesis.

Additionally, creatine may play a role in glycogen synthesis, mediated by drawing water via an osmotic effect into the intracellular compartment. ${ }^{5,74}$

It is, however, important to note that some people might be non-responders to creatine supplementation and therefore not gain any benefit from it. ${ }^{39}$ The reason for this is not clear but might be linked to habitual dietary habits (fish and meat consumption), as well as muscle fibre composition. ${ }^{39}$

\section{Combination of protein with other substrates}

\section{$\mathrm{CHO}$ and protein}

The insulinotrophic and endocrine effects of combined protein and $\mathrm{CHO}$ may attenuate muscle breakdown ${ }^{64}$ and increase muscle protein synthesis. ${ }^{58}$ Chandler and co-work$\mathrm{ers}^{14}$ found significantly higher plasma insulin levels postexercise when experienced male weight lifters consumed isocaloric $\mathrm{CHO}(1.5 \mathrm{~g} \mathrm{CHO} / \mathrm{kg} \mathrm{BW} /$ serving) and $\mathrm{CHO}$-protein $(1.06 \mathrm{~g} \mathrm{CHO}+0.41 \mathrm{~g}$ protein $/ \mathrm{kg}$ BW/serving) supplements compared with an isocaloric protein only $(1.38 \mathrm{~g}$ protein $/ \mathrm{kg}$ $\mathrm{BW} /$ serving), as well as a control supplement. Furthermore, growth hormone levels were significantly greater with the $\mathrm{CHO}$-protein supplement at 6 hours post-exercise. The optimal $\mathrm{CHO}$ :protein ratio for muscle repair and anabolic hormonal milieu seem to be $4-7: 1 .^{58}$

\section{Combining protein, $\mathrm{CHO}$ and fat}

Roy and co-workers ${ }^{63}$ found that the addition of fat to a $\mathrm{CHO}$ and protein meal did not influence post-exercise muscle repair negatively. Furthermore, positive correlations have been shown between testosterone levels and the percentage of overall dietary fat, mono-unsaturated and saturated fat. However, a negative correlation with polyunsaturated-to-saturated fatty acid ratio was reported. ${ }^{45}$

\section{Practical considerations with protein ingestion}

Increasing the protein (and fat) content of a meal/beverage may decrease gastric emptying and subsequent intestinal absorption of nutrients. ${ }^{29}$ This is of practical importance when including protein in the before, during, or post-exercise $\mathrm{CHO}$ beverage seeing that it may ultimately delay $\mathrm{CHO}$ (glucose) absorption and availability for energy production and the regeneration of muscle glycogen stores, both critical factors for increased exercise performance and post-exercise recovery (as discussed earlier).

Additionally, delayed gastric emptying may contribute to feelings of stomach discomfort (fullness or bloatedness), which might dampen appetite and decrease the volume of food, and more specifically, the amount of $\mathrm{CHO}$ ingested in the post-exercise recovery period. As discussed earlier, when multiple exercise or competition sessions are performed within a day and recovery time is limited, decreased $\mathrm{CHO}$ intake and availability, as well as stomach discomfort may decrease the rate of recovery post-exercise and/or directly decrease exercise performance. Post-exercise protein ingestion should ideally not exceed $0.2-0.4 \mathrm{~g} / \mathrm{kg}$ $\mathrm{BW} /$ hour. Furthermore, oral ingestion of single amino acids in large doses should be avoided as it may cause gastrointestinal upset and diarrhoea. ${ }^{73}$

Lastly, long-term excessive protein and/or amino acid intake (> $2 \mathrm{~g} / \mathrm{kg} \mathrm{BW} /$ day) may contribute to overweight (especially if overall calorie intake is excessive), as well as increased urinary calcium losses, which could lead to the development of osteoporosis if calcium intake is inadequate. $^{23}$ Other adverse effects include hypotension, tumour stimulation, mental retardation, and fatty liver (for detailed review see Garlick ${ }^{23}$ ). 


\section{Conclusions}

Although athletes have a higher protein need than sedentary individuals to maintain a positive nitrogen balance, ingesting more protein (> $2 \mathrm{~g} / \mathrm{kg} \mathrm{BW} /$ day) than is needed to maintain this balance will not result in further enhancements in muscle repair and adaptation. In fact, excessive protein and/or amino acid intake may contribute to various adverse effects and gastro-intestinal upsets. The sooner protein is ingested post-exercise the faster the body is shifted into an anabolic environment, which is important for protein synthesis and adaptation. It seems that protein hydrolysates result in higher insulin secretions than intact protein. Furthermore adding leucine and phenylalanine to a protein hydrolysate could cause even greater insulin secretion, thereby creating an anabolic hormonal milieu. The insulinotrophic and endocrine effects of combined protein and $\mathrm{CHO}$ ingestion $(\sim 0.8 \mathrm{~g}$ $\mathrm{CHO} / \mathrm{kg} \mathrm{BW} /$ hour $+0.2-0.4 \mathrm{~g}$ protein $/ \mathrm{kg}$ BW/hour) may reduce muscle breakdown and increase muscle protein synthesis in the post-exercise period.

The effect of glutamine supplementation on immune function still needs further investigation to establish its clinical relevance. HMB supplementation seems to increase FFM and strength when untrained individuals start a training programme, with little proven benefits in trained individuals. Creatine supplementation seems to be beneficial during the recovery phase in terms of protein synthesis, gains in FFM and glycogen storage.

\section{Practical recommendations}

It is concluded from Part I and Part II of this contribution that macronutrient manipulation is a potential strategy to enhance recovery and the adaptation process post-exercise. It is, however, important to keep dietary advice individualised considering the complexity in which the endocrine system regulates cell function, the diverse mechanisms that control homeostasis, as well as genetic variability.

Considering the relevant literature discussed in Parts I and II of this article, the following recommendations for enhanced muscle repair and muscle glycogen storage postexercise are made:

\section{Short $\leq \mathbf{6}$ hours) recovery period}

- Ingest 1 - $1.5 \mathrm{~g}$ high $\mathrm{Gl} \mathrm{CHO} / \mathrm{kg} \mathrm{BW}$ immediately postexercise and at 15 - 60-minute intervals for 3 - 4 hours thereafter, OR $0.8 \mathrm{~g}$ high $\mathrm{GI} \mathrm{CHO}+0.2-0.4 \mathrm{~g}$ protein $/ \mathrm{kg}$ BW immediately post-exercise and at 15 - 60-minute intervals for $3-4$ hours thereafter. Practice with various amounts and combinations in order to establish individual tolerance and stomach comfort.

- Aim at an overall ingestion of $7-10 \mathrm{~g} \mathrm{CHO} / \mathrm{kg} \mathrm{BW}$ within a 24-hour period, especially when participating in multiday competition events.

- Do not exceed $2 \mathrm{~g}$ protein/kg BW/day.

- Opt for protein hydrolysates with added leucine and phenylalanine.

- Limit dietary fat intake since it could lower the GI of the $\mathrm{CHO}$ food and hence delay gastric emptying and the absorption and supply of nutrients to the muscle.

\section{Longer ( $>6$ hours) recovery period}

- Ingest 6 - $8 \mathrm{~g}$ low or high $\mathrm{Gl} \mathrm{CHO} / \mathrm{kg} \mathrm{BW} /$ day for a moderate-intensity training schedule.

- Ingest 7 - $10 \mathrm{~g}$ low and/or high $\mathrm{Gl} \mathrm{CHO} / \mathrm{kg} \mathrm{BW/day} \mathrm{for} \mathrm{a}$ strenuous or prolonged training or competition schedule, especially when participating in strenuous multi-day competition events.

- Ingest 1.2 - $1.8 \mathrm{~g}$ protein/kg BW/day for a resistance and/or endurance exercise training schedule.

- Do not exceed $2 \mathrm{~g}$ protein/kg BW/day.

- Athletes training at altitude can increase protein intake to $2.2 \mathrm{~g}$ protein/kg BW/day.

- The addition of fat to a meal or supplement does not have any negative impact as long as total amount of $\mathrm{CHO}$ and protein ingested are sufficient and a favourable body fat is maintained.

- When using creatine supplementation a loading phase may be followed consisting of $20 \mathrm{~g}$ creatine monohydrate powder/day for 3 - 5 days. This $20 \mathrm{~g}$ dose should be divided into $4 \times 5 \mathrm{~g}$ dosages, spread out over the course of a day. Then, proceed to the maintenance phase consisting of ingesting a single dose of 2 - $5 \mathrm{~g}$ creatine/day. However, employing a loading phase is not critical or necessary. The creatine monohydrate is better absorbed when mixed into a high $\mathrm{GI} \mathrm{CHO}$ beverage such as a $\mathrm{CHO}$ sports drink (providing $\sim 30 \mathrm{~g}$ of a high $\mathrm{Gl} \mathrm{CHO}$ source for every $5 \mathrm{~g}$ creatine ingested).

- If embarking on a training programme, the addition of 1.5 - $3 \mathrm{~g} \mathrm{HMB/day}$ to creatine supplementation could contribute to further increases in strength and FFM.

- The assistance of a sports dietitian may be valuable to help implement the above recommendations, tailoring them according to individual needs and circumstances and encompassing the bigger picture of overall sound nutrition to optimise sporting performance and health.

\section{REFERENCES}

1. American Dietetic Association, Dietitians of Canada, and the American College of Sports Medicine Position Statement. Nutrition and athletic performance. J Am Diet Assoc 2000; 100: 1543-56.

2. Ardawi MS, Newsholme EA. Glutamine metabolism in lymphocytes of the rat. Biochem J 1983; 212: 835-42.

3. Bazzoli DL, Hill S, DiSilvestro RA. Soy protein antioxidant actions in active, young women. Nutr Res 2002; 22: 807-15.

4. Beduschi G. Current popular ergogenic aids used in sports: a critical review. Nutrition and Dietetics 2003; 60: 104-18.

5. Bemben MG, Bemben DA, Loftiss DD, Knehans AW. Creatine supplementation during resistance training in college football athletes. Med Sci Sports Exerc 2001; 33: 1667-73.

6. Biolo G, Tipton KD, Klein S, Wolfe RR. An abundant supply of amino acids enhances the metabolic effect of exercise on muscle protein. Am J Physiol 1997; 273: E122-9.

7. Blachier F, Mourtada A, Sener A, Malaisse WJ. Stimulus-secretion coupling of arginine-induced insulin release. Uptake of metabolized and nonmetabolized cationic amino acids by pancreatic islets. Endocrinology 1989; 124: 134-41.

8. Blomstrand E, Hassmen P, Ek S, Ekblom B, Newsholme EA. Influence of ingesting a solution of branched-chain amino acids on perceived exertion during exercise. Acta Physiol Scand 1997; 159: 41-9.

9. Blomstrand E, Newsholme EA. Effect of branched-chain amino acid supplementation on the exercise-induced change in aromatic amino acid concentration in human muscle. Acta Physiol Scand 1992; 146: 293-8.

10. Blomstrand E, Saltin B. BCAA intake affects protein metabolism in muscle 
after but not during exercise in humans. Am J Physiol Endocrinol Metab 2001; 281: E365-74

11. Borsheim E, Tipton KD, Wolf SE, Wolfe RR. Essential amino acids and muscle protein recovery from resistance exercise. Am J Physiol Endocrinol Metab 2002; 283: E648-57.

12. Bounous G, Batist G, Gold P. Immunoenhancing property of dietary whey protein in mice: role of glutathione. Clin Invest Med 1989; 12: 154-61.

13. Brouns F, Beckers E, Wagenmakers AJ, Saris WH. Ammonia accumulation during highly intensive long-lasting cycling: individual observations. Int J Sports Med 1990; 11: Suppl 2, S78-84.

14. Chandler RM, Byrne HK, Patterson JG, Ivy JL. Dietary supplements affect the anabolic hormones after weight-training exercise. J Appl Physiol 1994 76: 839-45.

15. Clark RH, Feleke G, Din M, et al. Nutritional treatment for acquired immunodeficiency virus-associated wasting using beta-hydroxy beta-methylbutyrate, glutamine, and arginine: a randomized, double-blind placebo-controlled study. J Parenter Enteral Nutr 2000; 24: 133-9.

16. Clarkson PM, Sayers SP. Etiology of exercise-induced muscle damage Can J Appl Physiol 1999; 24: 234-48.

17. Coombes JS, McNaughton LR. Effects of branched-chain amino acid supplementation on serum creatine kinase and lactate dehydrogenase after prolonged exercise. J Sports Med Phys Fitness 2000; 40: 240-6.

18. di Luigi L, Guidetti L, Pigozzi F, et al. Acute amino acids supplementation enhances pituitary responsiveness in athletes. Med Sci Sports Exerc 1999; 31: 1748-54.

19. Esmarck B, Andersen JL, Olsen S, Richter EA, Mizuno M, Kjaer M. Timing of postexercise protein intake is important for muscle hypertrophy with resistance training in elderly humans. J Physiol 2001; 535: 301-11.

20. Floyd JC jun., Fajans SS, Conn JW, Thiffault C, Knopf RF, Guntsche E. Secretion of insulin induced by amino acids and glucose in diabetes mellitus. J Clin Endocrinol Metab 1968; 28: 266-76.

21. Fry $A C$, Kraemer WJ, Stone $\mathrm{MH}$, et al. Endocrine and performance responses to high volume training and amino acid supplementation in elite junior weightlifters. Int J Sport Nutr 1993; 3: 306-22.

22. Gallagher PM, Carrithers JA, Godard MP, Schulze KE, Trappe SW. Betahydroxy-beta-methylbutyrate ingestion, Part I: effects on strength and fat free mass. Med Sci Sports Exerc 2000; 32: 2109-15.

23. Garlick PJ. Assessment of the safety of glutamine and other amino acids. J Nutr 2001; 131: 2556S-61S.

24. Hall JC, Heel K, McCauley R. Glutamine. Br J Surg 1996; 83: 305-12.

25. Hankard RG, Darmaun D, Sager BK, D'Amore D, Parsons WR, Haymond $\mathrm{M}$. Response of glutamine metabolism to exogenous glutamine in humans. Am J Physiol 1995; 269: E663-70.

26. Hankard RG, Haymond MW, Darmaun D. Effect of glutamine on leucine metabolism in humans. Am J Physiol 1996; 271: E748-54.

27. Hespel P, Eijnde BO, Derave W, Richter EA. Creatine supplementation: exploring the role of the creatine kinase/phosphocreatine system in human muscle. Can J Appl Physiol 2001; 26: Suppl, S79-102.

28. Incledon T, Antonio J. The anticatabolics. In: Antonio J, Stout JR, eds Sports Supplements. Philadelphia: Lippincott Williams and Wilkins, 2001 111-36.

29. Jenkins DJ, Kendall CW, Augustin LS, et al. Glycemic index: overview of implications in health and disease. Am J Clin Nutr 2002; 76(1): 266S-73S.

30. Jowko $E$, Ostaszewski $P$, Jank $M$, et al. Creatine and beta-hydroxy-betamethylbutyrate (HMB) additively increase lean body mass and muscle strength during a weight-training program. Nutrition 2001; 17: 558-66.

31. Juhn MS, Tarnopolsky M. Potential side effects of oral creatine supplementation: a critical review. Clin J Sport Med 1998; 8: 298-304.

32. Knitter AE, Panton L, Rathmacher JA, Petersen A, Sharp R. Effects of beta-hydroxy-beta-methylbutyrate on muscle damage after a prolonged run. J Appl Physiol 2000; 89: 1340-4.

33. Kreider RB, Ferreira M, Wilson M, Almada AL. Effects of calcium betahydroxy-beta-methylbutyrate (HMB) supplementation during resistancetraining on markers of catabolism, body composition and strength. Int $J$ Sports Med 1999; 20: 503-9.

34. Kreider RB, Ferreira M, Wilson M, et al. Effects of creatine supplementation on body composition, strength, and sprint performance. Med Sci Sports Exerc 1998; 30: 73-82.

35. Kreider RB, Miriel V, Bertun E. Amino acid supplementation and exercise performance. Analysis of the proposed ergogenic value. Sports Med 1993; 16: $190-209$.

36. Lambert MI, Hefer JA, Millar RP, Macfarlane PW. Failure of commercial oral amino acid supplements to increase serum growth hormone concentrations in male body-builders. Int J Sport Nutr 1993; 3: 298-305.

37. Lancha Junior AH, Santos MF, Palanch AC, Curi R. Supplementation of aspartate, asparagine and carnitine in the diet causes marked changes in the ultrastructure of soleus muscle. J Submicrosc Cytol Pathol 1997; 29 405-8

38. Lands LC, Grey VL, Smountas AA. Effect of supplementation with a cysteine donor on muscular performance. J Appl Physiol 1999; 87: 1381-5.

39. Lemon PW. Dietary creatine supplementation and exercise performance: why inconsistent results? Can J Appl Physiol 2002; 27: 663-81.

40. Lemon PW, Tarnopolsky MA, MacDougall JD, Atkinson SA. Protein requirements and muscle mass/strength changes during intensive training in novice bodybuilders. J Appl Physiol 1992; 73: 767-75.

41. Levenhagen DK, Carr C, Carlson MG, Maron DJ, Borel MJ, Flakoll PJ Postexercise protein intake enhances whole-body and leg protein accretion in humans. Med Sci Sports Exerc 2002; 34: 828-37.

42. Levenhagen DK, Gresham JD, Carlson MG, Maron DJ, Borel MJ, Flakol PJ. Postexercise nutrient intake timing in humans is critical to recovery of leg glucose and protein homeostasis. Am J Physiol Endocrinol Metab 2001; 280: E982-93.

43. MacLean DA, Graham TE, Saltin B. Stimulation of muscle ammonia production during exercise following branched-chain amino acid supplementation in humans. J Physiol 1996; 493: 909-22.

44. May PE, Barber A, D'Olimpio JT, Hourihane A, Abumrad NN. Reversal of cancer-related wasting using oral supplementation with a combination of beta-hydroxy-beta-methylbutyrate, arginine, and glutamine. Am J Surg 2002; 183: 471-9.

45. McCargar LJ, Clandinin MT, Belcastro AN, Walker K. Dietary carbohydrate-to-fat ratio: influence on whole-body nitrogen retention, substrate utilization, and hormone response in healthy male subjects. Am J Clin Nutr 1989; 49: 1169-78.

46. Mittleman KD, Ricci MR, Bailey SP. Branched-chain amino acids prolong exercise during heat stress in men and women. Med Sci Sports Exerc 1998; 30: 83-91.

47. Nair KS, Schwartz RG, Welle S. Leucine as a regulator of whole body and skeletal muscle protein metabolism in humans. Am J Physiol 1992; 263: E928-34.

48. Newsholme EA. Biochemical mechanisms to explain immunosuppression in well-trained and overtrained athletes. Int J Sports Med 1994; 15: Suppl 3, S142-7.

49. Nissen SL, Abumrad NN. Nutritional role of the leucine metabolite betahydroxy beta-methylbutyrate (HMB). Nutritional Biochemistry 1997; 8 : 300-11.

50. Nissen SL, Sharp RL. Effect of dietary supplements on lean mass and strength gains with resistance exercise: a meta-analysis. J Appl Physio 2003; 94: 651-9.

51. O'Connor DM, Crowe MJ. Effects of beta-hydroxy-beta-methylbutyrate and creatine monohydrate supplementation on the aerobic and anaerobic capacity of highly trained athletes. J Sports Med Phys Fitness 2003; 43 64-8.

52. Panton LB, Rathmacher JA, Baier S, Nissen S. Nutritional supplementation of the leucine metabolite beta-hydroxy-beta-methylbutyrate $(\mathrm{hmb})$ during resistance training. Nutrition 2000; 16: 734-9.

53. Parise G, Mihic S, MacLennan D, Yarasheski KE, Tarnopolsky MA. Effects of acute creatine monohydrate supplementation on leucine kinetics and mixed-muscle protein synthesis. J Appl Physiol 2001; 91: 1041-7.

54. Phillips SM, Parise G, Roy BD, Tipton KD, Wolfe RR, Tamopolsky MA Resistance-training-induced adaptations in skeletal muscle protein turnover in the fed state. Can J Physiol Pharmacol 2002; 80: 1045-53.

55. Phillips SM, Tipton KD, Aarsland A, Wolf SE, Wolfe RR. Mixed muscle protein synthesis and breakdown after resistance exercise in humans. Am J Physiol 1997; 273: E99-107.

56. Pyne DB. Exercise-induced muscle damage and inflammation: a review. Australian Journal of Science and Medicine in Sport 1994; 26: 49-58.

57. Ransone J, Neighbors K, Lefavi R, Chromiak J. The effect of beta-hydroxy beta-methylbutyrate on muscular strength and body composition in collegiate football players. Journal of Strength and Conditioning Research 2003; 17: 34-9.

58. Rasmussen BB, Tipton KD, Miller SL, Wolf SE, Wolfe RR. An oral essential amino acid-carbohydrate supplement enhances muscle protein anabolism after resistance exercise. J Appl Physiol 2000; 88: 386-92.

59. Rohde T, Krzywkowski K, Pedersen BK. Glutamine, exercise, and the immune system--is there a link? Exerc Immunol Rev 1998; 4: 49-63.

60. Romijn JA, Coyle EF, Sidossis LS, et al. Regulation of endogenous fat and carbohydrate metabolism in relation to exercise intensity and duration. $A m$ J Physiol 1993; 265: E380-91.

61. Rosene MF, Finn KJ, Antonio J, Kattelmann K, Doyle M. The effects of glutamine supplementation on lean body mass and anaerobic performance during a weight reduction program. Med Sci Sports Exerc 1999; 31: S123. 
62. Rossi AL, Blostein Fujii A, DiSilvestro RA. Soy beverage consumption by young men: increased plasma total antioxidant status and decreased acute, exercise-induced muscle damage. Journal of Nutraceuticals, Functional and Medical Foods 2000; 3: 33-44.

63. Roy BD, Fowles JR, Hill R, Tarnopolsky MA. Macronutrient intake and whole body protein metabolism following resistance exercise. Med Sci Sports Exerc 2000; 32: 1412-8.

64. Roy BD, Tarnopolsky MA, MacDougall JD, Fowles J, Yarasheski KE. Effect of glucose supplement timing on protein metabolism after resistance training. J Appl Physiol 1997; 82: 1882-8.

65. Slater G, Jenkins D, Logan P, et al. Beta-hydroxy-beta-methylbutyrate (HMB) supplementation does not affect changes in strength or body composition during resistance training in trained men. International Journal of Sport Nutrition and Exercise Metabolism 2001; 11: 384-96.

66. Snyder AC, Naik J. Protein requirements of athletes. In: Berning JR, Steen $\mathrm{SN}$, eds. Nutrition for Sport and Exercise. Maryland: Aspen Publishers, 1998: 45-57.

67. Terjung RL, Clarkson P, Eichner ER, et al. American College of Sports Medicine roundtable. The physiological and health effects of oral creatine supplementation. Med Sci Sports Exerc 2000; 32: 706-17.

68. Tessari P, Barazzoni R, Zanetti M, Kiwanuka E, Tiengo A. The role of substrates in the regulation of protein metabolism. Baillieres Clin Endocrinol Metab 1996; 10: 511-32.

69. Tipton KD, Ferrando AA, Phillips SM, Doyle D jun., Wolfe RR. Postexercise net protein synthesis in human muscle from orally administered amino acids. Am J Physiol 1999; 276: E628-34.
70. Tipton KD, Rasmussen BB, Miller SL, et al. Timing of amino acid-carbohydrate ingestion alters anabolic response of muscle to resistance exercise. Am J Physiol Endocrinol Metab 2001; 281: E197-206.

71. Tipton KD, Wolfe RR. Exercise, protein metabolism, and muscle growth International Journal of Sport Nutrition and Exercise Metabolism 2001; 11 : 109-32.

72. van Loon LJ, Kruijshoop M, Verhagen H, Saris WH, Wagenmakers AJ. Ingestion of protein hydrolysate and amino acid-carbohydrate mixtures increases postexercise plasma insulin responses in men. J Nutr 2000; 130: $2508-13$.

73. van Loon LJ, Saris WH, Verhagen H, Wagenmakers AJ. Plasma insulin responses after ingestion of different amino acid or protein mixtures with carbohydrate. Am J Clin Nutr 2000; 72: 96-105.

74. Volek JS, Duncan ND, Mazzetti SA, et al. Performance and muscle fiber adaptations to creatine supplementation and heavy resistance training. Med Sci Sports Exerc 1999; 31: 1147-56.

75. Welbourne TC. Increased plasma bicarbonate and growth hormone after an oral glutamine load. Am J Clin Nutr 1995; 61: 1058-61.

76. Willoughby DS, Rosene J. Effects of oral creatine and resistance training on myosin heavy chain expression. Med Sci Sports Exerc 2001; 33: 167481.

77. Windmueller HG, Spaeth AE. Uptake and metabolism of plasma glutamine by the small intestine. Nutr Rev 1990; 48: 310-2.

78. Young VR. Soy protein in relation to human protein and amino acid nutrition J Am Diet Assoc 1991; 91: 828-35. 